\title{
Evaluation of potential habitat with an integrated analysis of a spatial conservation strategy for David's deer, Elaphurus davidians
}

\author{
S. B. Fang $\cdot$ X. S. Zhang $\cdot$ X. B. Jia $\cdot$ S. Q. An \\ C. F. Zhou • C. Xu
}

Received: 21 June 2007 / Accepted: 27 February 2008 / Published online: 12 April 2008

(C) The Author(s) 2008

\begin{abstract}
How to assess the potential habitat integrating landscape dynamics and population research, and how to reintroduce animals to potential habitats in environments highly human disturbed are still questions to be answered in conservation biology. According to behavioral research on Elaphurus davidians, we have developed a suitability index and a risk index to evaluate the potential habitats for the deer. With these indices, we conducted two transect assessments to evaluate the gradient change of the target region. Then, taking rivers as border lines, we tabulated the forest areas, high grassland area and total area and then compared the forest and high grassland area in each subregion. Furthermore, we computed the land use transfer matrix for the whole Yancheng coast during 1987-2000. We also computed human modified index (HMI) in six subregions. Lastly with a geographical information system support we obtained the spatial distribution of the indices and evaluation of the whole potential habitats from a neighborhood analysis. The transect assessment showed that the suitability of the coastal area was higher than that of the inland area for the deer, while the southern area was higher than the northern. Landscape metrics and HMI analysis showed
\end{abstract}

S. B. Fang $\cdot$ X. S. Zhang $\cdot$ X. B. Jia $\cdot$ S. Q. An $(\bowtie) \cdot$

C. F. Zhou $\cdot$ C. Xu

The State Key Laboratory of Pollution Control and Resource Reuse, the Institute of Wetland Ecology, School of Life Science, Nanjing University,

Nanjing 210093, China

e-mail: anshq@nju.edu.cn that different landscape patterns and different anthropogenic disturbance existed within the region, and the increasing human disturbance was the key factor causing the pattern dynamics. The evaluation of potential habitats showed that there was an estimated carrying capacity of no more than 10,000 for David's deer reintroduction into the natural area. Also the reintroduction strategy was discussed. This integrated approach linked the population research and the landscape metrics, and the dataset with different scale; thus, it is an approach likely to be useful for the protection of other large animal in a landscape highly disturbed by humans.

Keywords Large animal · Conservation strategies . Reintroduction · Milu research · Land use .

Landscape scale assessment

\section{Introduction}

Conservation of endangered large mammals in fragmented landscapes has become a central issue in conservation biology (Wikramanayake et al. 2004). When monitoring the population dynamics, more attentions has recently been paid to the use of landscape metrics (O’Neill et al. 1997; Lausch and Herzog 2002; Gergel et al. 2002; Brooks 2003; Brooks et al. 2004; Lenz and Peters 2006; Sepp and Bastian 2007). Using landscape metrics as indicators 
to study landscape change has been conducted in different cases recently (Uuemaa et al. 2005; Wiggering et al. 2006; Sepp and Bastian 2007; Olsen et al. 2007). Various research has provided some profound cases that landscape metrics could be very powerful for indicating the landscape status quo patterns, dynamics, and some background ecological processes ( $\mathrm{Li}$ et al. 2005; Mander et al. 2005; Muller 2005). Some research has tried to develop the landscape analysis for biodiversity conservation (Burel and Baudry 2005; Oja et al. 2005; Riitters 2005).

Spatial heterogeneity has an important influence on a range of ecological patterns and processes (Shugart 1998), and many landscape metrics in GIS environment are used to facilitate the investigation of the relation between landscape structure and biodiversity (Mladenoff et al. 1995; White et al. 1997; Wikramanayake et al. 1998, 2004; Liu et al. 1999; Hoctor et al. 2000; Akcakaya et al. 2004; Bhagwat et al. 2005; Burel and Baudry 2005; Oja et al. 2005; Riitters 2005; Schindler et al. 2008). Gap analysis attempts to map dominant land-cover types and vertebrate species distributions at the landscape level and to determine which are underrepresented in areas managed primarily for biodiversity (Caicco et al. 1995; Scott et al. 1996). These research provided us with a great deal of useful vision on the biodiversity conservation issue at landscape scale. But we think biodiversity conservation should integrate the background landscape dynamics with the target species population analysis ( $\mathrm{Li}$ and Reynolds 1994; Li and Wu 2004). Human disturbance is an important factor to be considered in a highly disturbed landscape. From literature's analysis and synthesis, we want to provide an integrated approach to solve the problems how to integrate the landscape dynamics with species population analysis. Taking Elaphurus davidianus (Milu or Père David's deer) as a case study, we try to answer some Milu conservation questions.

Milu is a large mammal native to China. For reasons such as natural climate change, increase of anthropogenic disturbance and species specialization (Ding 2005; Beijing Milu Ecological Experimental Center 2005; Ding et al. 2006), Milu became extinct in China about 100 years ago. From 1985, several batches of Milu were donated to China from Britain, and then some natural conservation areas were established such as Nanhaizi in Beijing, Dafeng in Jiangsu Province and Tian'e Zhou in Hubei Province. So far, China's
Milu population has increased nearly 20 times, from 67 in 1987 to 1,419 in 2003, and the population had been in a state of steady increase during this period. Because of the large Milu populations and the small size of conservation area in Dafeng, it is critical to release Milu into the wild coastal region (Beijing Milu Ecological Experimental Center 2005; Ding et al. 2006), and so assessing the potential habitat and determining the spatial reintroduction strategy is a very urgent issue (Beijing Milu Ecological Experimental Center 2005; Ding et al. 2006).

In this study we presented a simple approach integrating the landscape dynamics and the Milu population behavioral research to study the conservation strategy in Chinese Yancheng coast, where most of Milu population lived. We addressed two questions in this study: how to assess the Chinese Yancheng coastal region, integrating the landscape dynamics and the Milu population research, and how to reintroduce Milu in this region according our assessment.

\section{Study site}

The wetlands on the Yancheng coast are an appropriate region to establish a wild Milu population (Ding 2005). Milu originated from middle and eastern China, inhabiting the plain and marshlands in the Huang River basin and the Yangtze River basin (Ding 2005). Historically, because of the intensifying human pressures in the inner mainland, Milu migrated to the coastal region south of Huang River, from the west and north. They lived in this region until they became extinct in China (Ding 2005). Located in the middle of the Chinese coast, $32^{\circ} 34^{\prime} \sim 34^{\circ} 28^{\prime} \mathrm{N}, 119^{\circ} 27^{\prime} \sim 121^{\circ} 16^{\prime} \mathrm{E}$, the target coastal region is a typical coast of silt, sand and mud. This is an ecotone between different wetlands located in the Yellow Sea and Huai River plains, bound on the south by the Yangtze River, on the east by the Yellow Sea and on the north by the Yellow River. There are many small rivers and lakes in the area and it crosses two bioclimatic zones, the warm temperate zone and the northern subtropical zone. There is a large area of coast tidal flats, about $4.5 \times 10^{7}$ ha, which constitutes $70 \%$ of Jiangsu's tidal flats and $14.13 \%$ of the China. This is the largest reserve land in Jiangsu Province and even in China. There are two global important biodiversity conservation hotspots located here, the Red-Crowned Crane National Natural Reserve and the 
Milu National Natural Reserve (Dafeng). For its global significance to biodiversity conservation, in 1992 , Yancheng was listed in the world network of biosphere conservation (WNBP) by the United Nations.

In China, the coastal region is defined as the area between $10 \mathrm{~km}$ inland and the $15 \mathrm{~m}$ depth contour in the sea. In this study according to the requirement of Milu research, we only consider the inland part of the region and the buffer distance is extended to $30 \mathrm{~km}$ inland (Fig. 1).

\section{Methods}

Main analysis process

The recent work of Brook et al. (2004) presented a simple and time-saving approach to assess an ecosystem's ecological status or integrity. The Landscape Development Intensity index (Brown and Vivas 2005) provided an independent, quantitative and reproducible measure of the anthropogenic disturbance gradient. In most parts of the world, land use and land-cover change (LUCC) was considered to be an interface between natural conditions and anthropogenic influence (Lausch and Herzog 2002). These researches provided us some guidance for the quantitative study of human disturbance on landscape dynamics.
First, according to Dafeng Milu's behavioral ecology research, we defined a suitability index $\mathrm{V}$ to evaluate the potential habitat suitability for Milu. This index mainly reflects Milu's preferred habitat choice, where they can get food and shelter. According to the analysis of typical human activity in Yancheng, we defined a risk index R. This index should mainly reflect the human disturbance on the land-use dynamics.

Secondly, using Yancheng land-use data, based on these indices we conducted spatial scan statistics in the Yancheng coastal region, using statistics circles (Center for Statistical Ecology and Environmental Statistics 2006). There are some rigorous and complicated mathematical basics for using statistics circles in the spatial statistics process (Center for Statistical Ecology and Environmental Statistics 2006). This approach is more effective when using synoptic data such as land use (Center for Statistical Ecology and Environmental Statistics 2006). Taking a circle's center as the point, it assesses the point information within the statistics circle (Center for Statistical Ecology and Environmental Statistics 2006). If more points are selected on a transect, we could know its whole status of suitableness or risk.

Thirdly, taking rivers as border lines we divided the region into 6 subregions and in each subregion we tabulated the forest area, high grassland area and total area and then compared forest and high grassland

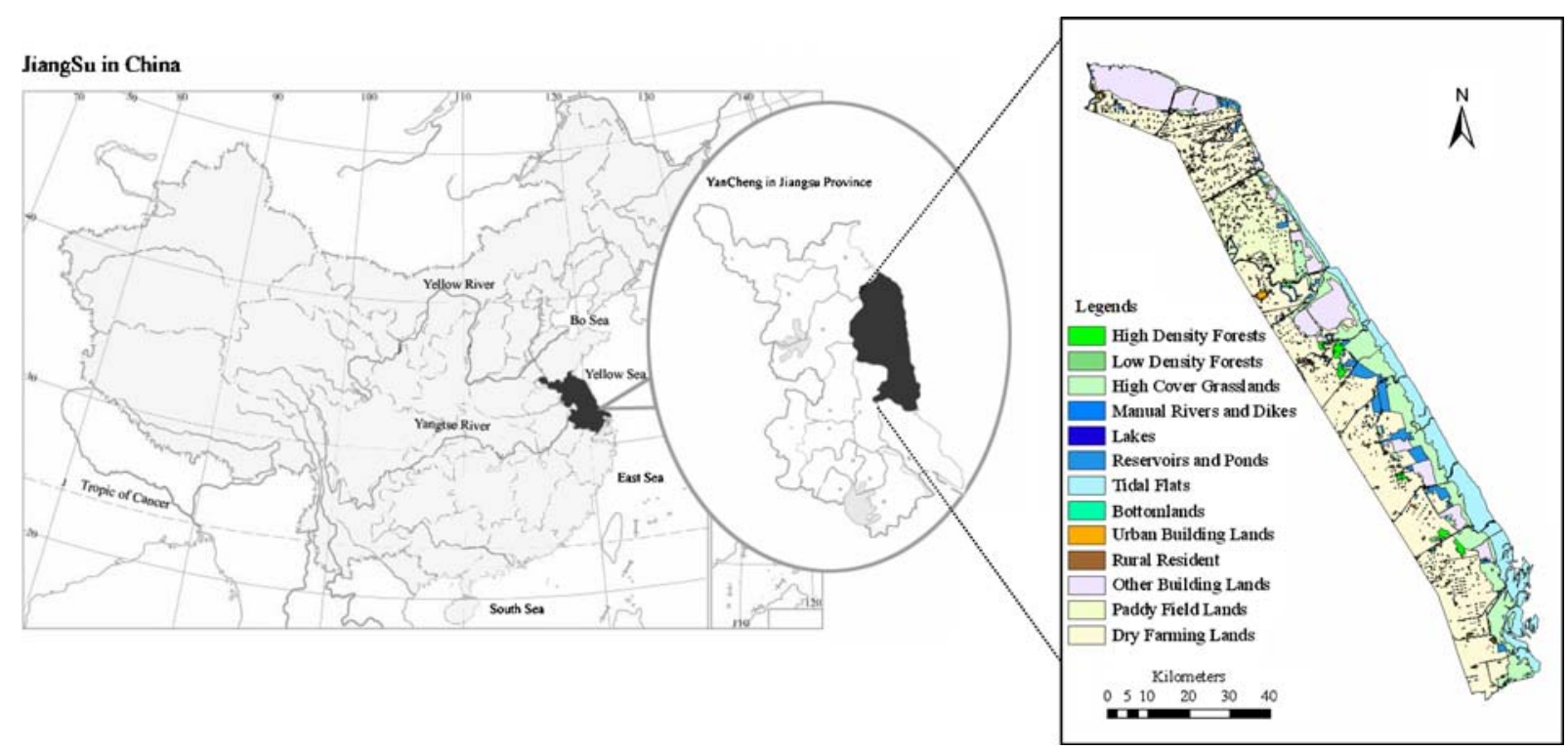

Fig. 1 Study site in Yancheng coast (land use in 2000). Yancheng coast is our target site in this study. Milu migrated and lived in this region until they became extinct 
area. Then, we computed the human modified index (HMI) in each subregion. HMI is a reflection of the human disturbance on the environment, and all landuse types were included in this computing process. Lastly we computed the land-use transfer matrix of the whole region during 1987-2000. Landscape metrics analysis is a quantitative method to reflect the landscape change (Turner and Gardner 1990; Forman 1995; Zonneveld 1995; Riitters et al. 1995; Turner et al. 2001). Series time landscape pattern analysis could effectively reveal the driving forces causing the change (Turner and Gardner 1990). An appropriate landscape pattern can help to conserve the target species (O’Neill et al. 1997). Many mature methods have been designed to analyze landscape pattern till now (O’Neill et al. 1988; Forman 1995). We analyze three periods' landscape metrics, 1987, 1995 and 2000, and through the analysis we wanted to determine the anthropogenic disturbance dynamic during this time.

Fourthly, we transferred the vector land-use data into vaster data. Taking the average $V$ index value computed in the first step as the threshold, we found the spatial distribution of the two indices values. Time span of our data was only from 1987 to 2000 . In fact, since 2000 , more and more coastal wetlands have been developed into aquaculture lands or agriculture lands or building lands. Taking the average $V$ index value as the threshold might be used to satisfy the management needs. The region that $V$ index value beyond which should be conserved and in which human disturbance should be ruled. For $R$ index, we also adopted this threshold because it was enough with which we could know its distribution and dynamics. If one individual Milu needs 6 ha of grasslands per year, we could obtain an estimated carrying capacity of this region. Also, according to the indices distribution map, we hoped to produce a plausible reintroduction strategy for Milu.

Lastly, we integrated the results of these two methods and tried to answer the question posed in the introduction: (a) How to assess the Chinese Yancheng coastal region, integrating the landscape dynamics and the Milu population research and (b) how to reintroduce Milu in Chinese Yancheng coast according the assessment. Land-use data at a scale of 1:100,000 in Yancheng was the basic analysis data (Fig. 1).
Suitability and risk assessment

Size of the statistical circle and the transect analysis

Status and trends in landscape potential for specific wildlife can be quantified (Danielson 1992). O'Neill et al. (1997) proposed constructing a window the size of an organism's home range. Within the window we could determine whether this range was suitable for the organism, with the habitat requirement analysis, such as vegetation mixture, edge, and available water. By moving the window systematically over the map, we could yield an overall indicator of the status of the landscape for this organism. Brooks et al. (2004) described the development and use of synoptic landcover maps (Level 1) to assess wetland conditions for a watershed. They computed the disturbance score based on land cover in 1-km radius circles centered on randomly-selected wetlands in each watershed. Their results showed that this was useful in reflecting the wetlands condition. Compared to other two levels assessment, this process could be conducted in a geographic information system (GIS) - capable office with rapidly available data and without engaging in extensive field investigations. Abbruzzese and Leibowitz (1997) provided a simple computation expression as synoptic indices to assess the cumulative impacts on wetlands, including the wetlands loss index and future risk index to wetlands. Our analyzing process was based on these valuable ideas. Now for there was no persuasive research about the size of the Milu home range, we referenced the size of the core region.

Referencing the range of Dafeng reserves $(78,000$ ha in total, 2,667 ha the core region, Fig. 2, the cross), we drew a $3 \mathrm{~km}$ radius circle, which could just cover the core region. Then a transect was drawn which was nearly parallel to the Yancheng coast line, and the transect should just pass through the centre of the Dafeng circle (Fig. 2, the cross). On the transect, from the Dafeng circle, from south to north, we drew the same size circle every $15 \mathrm{~km}$. So there were 15 circles on this transect in total. In every circle, we computed the percentage of each land-use type's area to get the values of the suitability index and the risk index (O’Neill et al. 1997; Patil and Taillie 2001; Brooks 2003, 2004; Miller and Wardrop 2006). At a distance of $6 \mathrm{~km}$ away towards the coast from the first transect, a similar transect was drawn with another 15 circles 


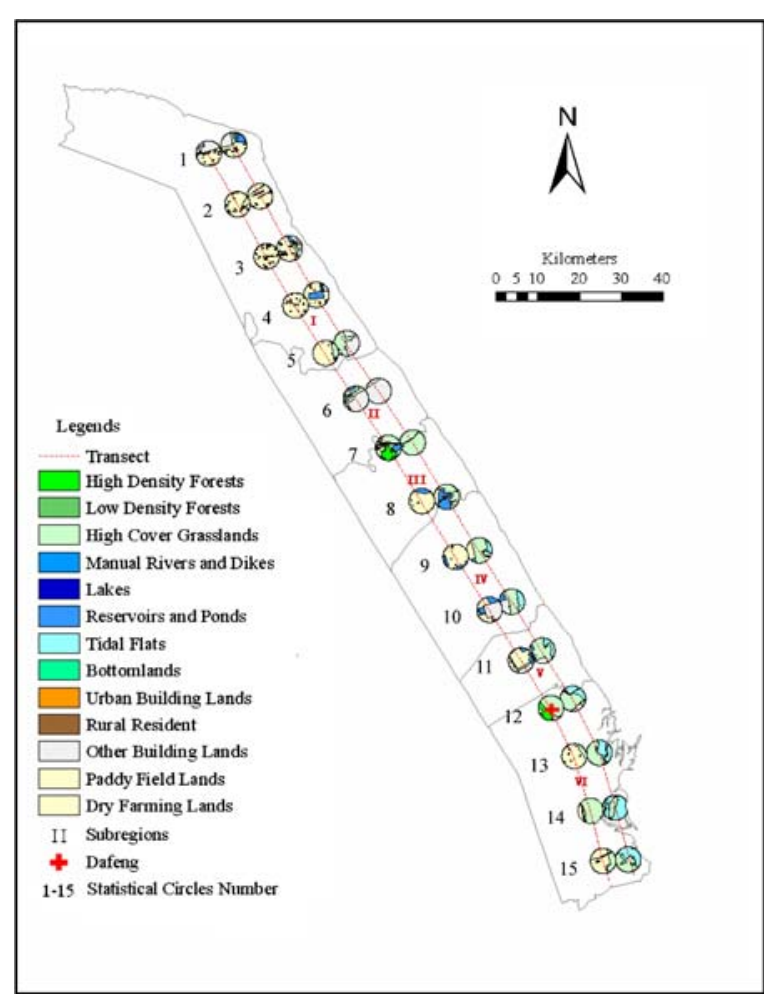

Fig. 2 Transect analyses in Yancheng coast. Referencing the core region range of Dafeng Milu Natural Reserve area $(2,667 \mathrm{ha})$, we took the $3 \mathrm{~km}$ radius circle as our spatial scan statistics unit. Two transect analyzing were conducted, from coast to inland, and 15 circles on each transect

and the same indices were computed (Fig. 2). Thus there were 30 statistics circles altogether, 15 on each transect.

In this way we computed the indices for three years, 1987, 1995 and 2000.

\section{Suitability assessment index}

According to the behavioral research in Dafeng, food, water and shelter are the most critical elements for a suitable Milu habitat (Ding 2005; Beijing Milu Ecological Experimental Center 2005; Ding et al. 2006). Taken not only as food but also as shelter, the vegetation landuse was used to identify suitable habitat areas for Milu (Ding 2005; Beijing Milu Ecological Experimental Center 2005; Ding et al. 2006). Within our land-use data, only the forests lands type and the high grasslands type could reflect the Milu's favorite habitat choice, so we chose the forest and the high cover grassland as the land-cover type which we analyzed as follows to get index values (O’Neill et al. 1997; Miller and Wardrop 2006; Abbruzzese and Leibowitz 1997). We defined $V$, the suitability index as:

$V=W_{\mathrm{F}} P_{\mathrm{F}}+W_{\mathrm{G}} P_{\mathrm{G}}$

$V$ : Suitability index value

Where $W_{\mathrm{F}}$ and $W_{\mathrm{G}}$ were the weights of land-cover forest and high cover grassland, respectively, and $P_{\mathrm{F}}$ and $P_{\mathrm{G}}$ were the percentage of the forest and high cover grassland area, respectively, in each statistics circle.

\section{Risk assessment index}

On the Yancheng coast, agriculture and other intensive human disturbance activities, including salt field development, aquaculture development, harbor building and industrial factory building are the main human activities causing negative impacts on the coastal environment. These activities always fragment the potential habitat and destroy the ecosystems' integrity. In this study we took the land-cover types agriculture and building land as the data with which we do the risk assessment (Ding 2005; Beijing Milu Ecological Experimental Center 2005; Ding et al. 2006). We define $R$, the risk index as:

$R=W_{\mathrm{A}} P_{\mathrm{A}}+W_{\mathrm{B}} P_{\mathrm{B}}$

\section{$R$ : risk index value}

Where $W_{\mathrm{A}}$ and $W_{\mathrm{B}}$ were the weights of land-cover farm lands and building lands, respectively, and $P_{\mathrm{A}}$ and $P_{\mathrm{B}}$ were the percentage of farm land and building land areas, respectively, in each circle.

According to Dafeng Milu research report, forest land cover is more important to Milu than grassland in its life history. So in the analysis, according to the experts' opinion, we determined that $W_{\mathrm{F}}$ was 0.6 , and $\mathrm{W}_{\mathrm{G}}$ 0.4. For the risk assessment, given that it was less harmful to Milu compared with other building activities such as industrial and aquiculture, we determined that $W_{\mathrm{A}}$ was 0.4 , and $W_{\mathrm{B}} 0.6$. It was not appreciate to lump the natural and plantation forests together here. But because of not enough natural forests, more Milu were fed in the plantation forests. In fact, in Dafeng, most forests were plantation forests. So in this study we lumped the forest together (Table 1). 
Table 1 Landcover types, relation to $R$ and $V$ indices and HMI parameters

\begin{tabular}{|c|c|c|c|c|}
\hline ID & $\begin{array}{l}\text { Land-cover } \\
\text { types }\end{array}$ & Explanations & $\begin{array}{l}\text { Relations to } \\
R \text { or } V\end{array}$ & $\begin{array}{l}\text { HMI } \\
\text { parameters }\end{array}$ \\
\hline 113 & Paddy field lands & $\begin{array}{l}\text { Lands with enough irrigating, such as rice or lotus farming, } \\
\text { paddy fields and dry lands rotation lands included }\end{array}$ & $R$ & 0.8 \\
\hline 123 & Dry farming lands & $\begin{array}{l}\text { Lands depending on natural precipitation; dry lands can be } \\
\text { irrigated in a years; vegetable farming lands; fallow cropping lands }\end{array}$ & $R$ & 0.8 \\
\hline 21 & High density forests & $\begin{array}{l}\text { Natural or plantation forests with canopy density }>30 \% \text {; timber forests, } \\
\text { protection forests and economic forests included }\end{array}$ & $V$ & 0.5 \\
\hline 24 & Low density forests & $\begin{array}{l}\text { Afforestation woodlands no canopy, blanks, nursery gardens and } \\
\text { garden plots including orchards, mulberry orchards, tea farms } \\
\text { and tropical woodlands farming lands }\end{array}$ & $V$ & 0.5 \\
\hline 31 & High cover grasslands & $\begin{array}{l}\text { Grasslands with coverage }>50 \% \text {, with enough water supplying, } \\
\text { including natural grasslands, improved grasslands and cutting grasslands }\end{array}$ & $V$ & 0.4 \\
\hline 41 & Manual rivers and dikes & $\begin{array}{l}\text { Natural or manual digging rivers and dikes, including lands below } \\
\text { the perennial flood level of the main canal }\end{array}$ & $R$ & 0.7 \\
\hline 43 & Reservoirs and ponds & Lands below the perennial flood level of manual reservoirs & - & 0.6 \\
\hline 45 & Tidal flats & Tidal zones between the high and low tidal level in coastal regions & - & 0.3 \\
\hline 46 & Bottomlands & $\begin{array}{l}\text { Lands between the water level of flood period and level period; } \\
\text { including rivers or lakes }\end{array}$ & - & 0.3 \\
\hline 51 & Urban building lands & Building lands in big, mid, or small cities or counties & $R$ & 1.0 \\
\hline 52 & Rural resident & Lands for rural settlements & $R$ & 0.9 \\
\hline 53 & Other building lands & $\begin{array}{l}\text { Independent building lands, not in a city, such as factories } \\
\text { and mines, large industrial districts, oil fields, salt fields, } \\
\text { stone pits, traffic lands, air ports and special lands }\end{array}$ & $R$ & 1.0 \\
\hline
\end{tabular}

"ID" referring to the classifying code of the dataset we used; "Relations to $R$ and $V$ " means that this landcover type should be included in the $V$ or $R$ indices analyzing process; "HMI" referring to human modified index, the parameters meaning its indicating intensity relating to human disturbance

For suitability assessment, we referenced the spatial statistics index value in the Dafeng and standardized other spatial circles' index value in $0-1$. The natural conservation areas are always thought few or none human disturbance so they are always rated as the referencing sites to assess the ecosystem's integrity (Brooks et al. 2004). In the ecological restoration work, these areas are also taken as the standard to determine whether a restoration project is successful or not. And of the entire circle's valuability index's value, the value in Dafeng was the highest. For risk assessment, referencing the maximum index value of all the spatial circles in all three times, we standardized all $R$ index value in $0-1$.

Then we compared the $V$ and $R$ index values on each transect and between the two transects. The $V$ and $R$ values are on the whole negatively correlated. They were designed to reflect the different information for Milu's reintroduction. If $V$ is higher, the site is more suitable for Milu, but if $R$ is higher, it is less suitable for Milu.
Landscape analysis on potential habitat of Milu

On the Yancheng coast, using the river borderlines, we divided it into six subregions, I, II, III, IV, V and VI, from north to south (Fig. 2). In each subregion, we computed land-use metrics and human modified index.

\section{Land-use metrics analysis}

Using the software Fragstats (McGarigal and Marks 1995), we computed each land-cover type's area (O’Neill et al. 1997; Brooks 2003; Brooks et al. 2004; Miller and Wardrop 2006). For the importance to Milu, using the software ARCVIEW 3.3 (ESRI 1993) we tabulated the forest area, high grassland area and total area and then compared forest and high grassland area in each subregion. Lastly we computed the land-use transfer matrix in the whole Yancheng coast during time 1987-1995 and 1995-2000, to analyze the land-use dynamics of the whole region. 


\section{Human modified index}

We adopted the human modified index (HMI) proposed by Zeng (Zeng et al. 1999; Jiao 2003) to compute the human activity intensity as follows:

$\mathrm{HMI}=\sum_{i=1}^{n} \frac{A_{i} P_{i}}{\mathrm{TA}}$

HMI is the index value, $\mathrm{n}$ the landscape elements' type number, $\mathrm{A}_{\mathrm{i}}$ the total area of the number $i$ landscape element, $P_{i}$ the HMI parameter of the number $i$ landscape elements and TA the total area. For $P_{i}$, referencing the parameters defined by Jiao (Jiao 2003), we assigned land-cover tidal flat and bottomland Pi 0.3 ; others from 0.3 to 1.0 (Table 1). We computed the total HMI value in each subregion using Excel software (Jiao 2003).

\section{$V$ and $R$ value distribution on the whole region}

If we know the spatial distribution of the $V$ and $R$ values through the whole region, we can know where is more suitable for Milu and where is not so suitable. We transferred our vector land-use data to raster form and with the software ARCVIEW 3.3 (ESRI 1993), using the $1 \mathrm{~km}$ window we did the $\mathrm{V}$ and $\mathrm{R}$ indices neighborhood analysis.

\section{Datasets}

\section{Land-use data}

Land-use data was obtained from the Resources and Environment Science Data Center (RESDC), Chinese Academy of Science, 1:100,000, from 1987 to 2000.

\section{Milu research report}

The reports were obtained from Milu research in China (Ding 2005) and Milu conservation and research (Printed collection of thesis, Ding et al. 2006).

\section{Results}

Suitability and risk assessment

Generally, regions with high $\mathrm{V}$ index value located in the southern Yancheng coastal region, and the region around Dafeng were considered more appropriate to reintroduce Milu. On the other hand, regions with high $R$ value were mainly located in the northern Yancheng coastal region, which indicated a more intensive human activity. This was the case on both transects. There clearly existed a gradient from coast to the inland area; the average $V$ value was higher and the average $R$ value was lower on the coast (Fig. 3).

Comparing the indices values for the three years 1987, 1995 and 2000 showed that there was little difference from 1987 to 1995 (Fig. 3), but between 1995 and 2000 the indices' values changed more. From 1987 to 2000 , on both transects, the $V$ index value decreased while the $R$ index value increased. The $R$ index value mainly reflected the human disturbance, which was rated as the risk to Milu's habitat integrity. So these trends indicated that from the mid 1990s human disturbance became more and more strong.

Landscape analysis on Milu's potential habitat

\section{Landscape metrics}

There was only a small percentage of forest land cover in each subregion, and the biggest percentage subregion was region III, with $3.4 \%$, while in subregion I there was no forest lands cover at all. From 1987 to 2000, the forest land cover hardly changed any more. The high cover grassland area was larger in each subregion and changed more from 1987 to 2000 . The grassland areas were more than $20 \%$ in each subregion except subregion I (Table 2).

During the period 1987-1995, there was only a small scale transfer between different land-use types. For the dry lands, both in-transferring and outtransferring happened, but forest land-cover area did not change. For the high cover grassland, there were 46 ha land transferring in and no other land transferring out (Table 3, the left column reflected the out-transferring land cover, and the top row reflected the in-transferring land cover. This was also Table 4).

During the period 1995-2000, there was a larger scale of land-use transfer, except for the forest land cover which was still hardly changed (Table 4). The high cover grasslands were transferred to a large extent, 9,571 ha high cover grassland was transferred to reservoirs and ponds, 7,466 ha to other building 


\section{a}

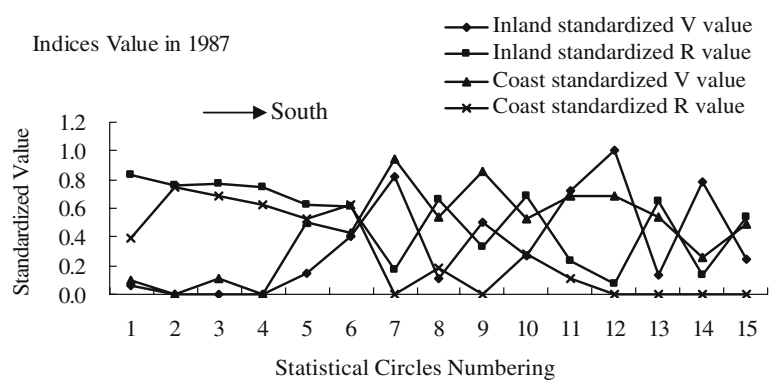

C

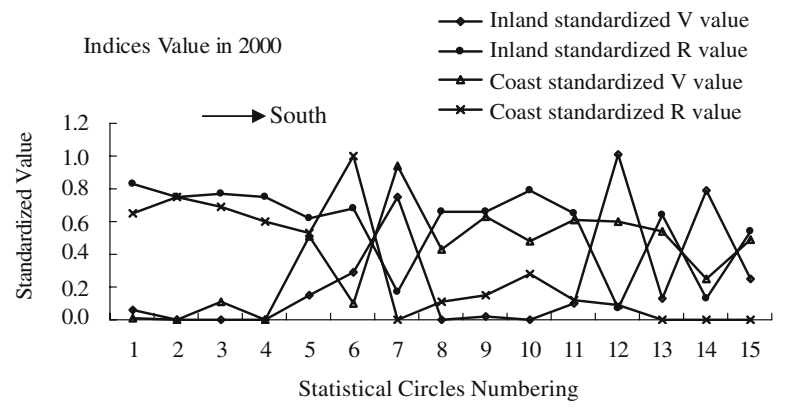

b Indices Value in 1995 $\rightarrow$ Inland standardized $\mathrm{R}$ value $\longrightarrow$ Coast standardized $\mathrm{V}$ value $\rightarrow$ Coast standardized $R$ value

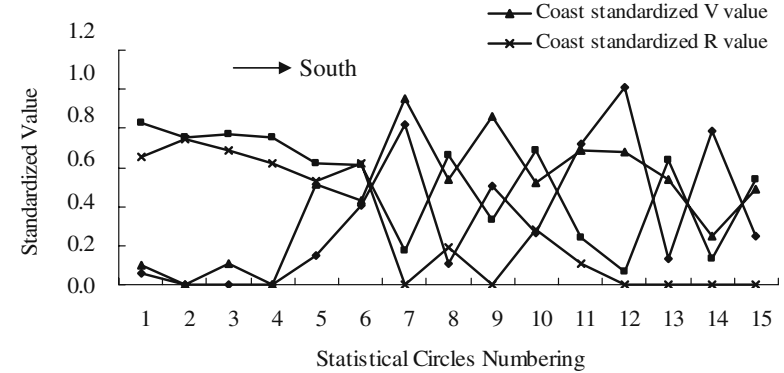

d

Ga Inland standardized $\mathrm{V}$ value :; Inland standardized $\mathrm{R}$ value E.: Coast standardized $\mathrm{V}$ value

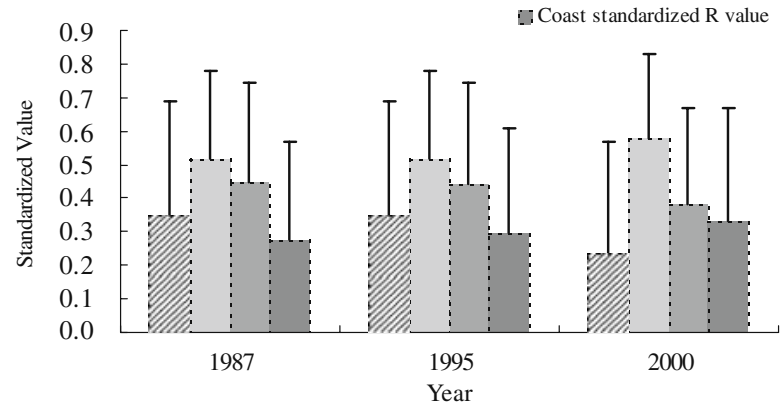

Fig. 3 Transect analysis results in Yancheng coast. Subpanels a, b and $\mathbf{c}$ showed the indices dynamics from 1987 to 2000 . V and R all have a high standard error $\mathbf{d}$. This reflected the high land-cover heterogeneity in Yancheng coast

Table 2 Forest and high cover grassland areas, percentage and total area (ha) from 1987 to 2000

\begin{tabular}{|c|c|c|c|c|c|c|}
\hline Subregions & Year & Forests (ha) & Forest Percentage (\%) & Grasslands (ha) & Grassland Percentage (\%) & Total Area (ha) \\
\hline \multirow[t]{3}{*}{ I } & 1987 & 0 & 0.00 & 12,509 & 6.71 & \multirow[t]{3}{*}{186,522} \\
\hline & 1995 & 0 & 0.00 & 12,508 & 6.71 & \\
\hline & 2000 & 0 & 0.00 & 12,346 & 6.62 & \\
\hline \multirow[t]{3}{*}{ II } & 1987 & 579 & 0.81 & 18,631 & 26.20 & \multirow[t]{3}{*}{71,110} \\
\hline & 1995 & 578 & 0.81 & 18,631 & 26.20 & \\
\hline & 2000 & 578 & 0.81 & 9,671 & 13.60 & \\
\hline \multirow[t]{3}{*}{ III } & 1987 & 1,953 & 3.40 & 13,455 & 23.42 & \multirow[t]{3}{*}{57,447} \\
\hline & 1995 & 1,953 & 3.40 & 13,501 & 23.50 & \\
\hline & 2000 & 1,953 & 3.40 & 11,389 & 19.83 & \\
\hline \multirow[t]{3}{*}{ IV } & 1987 & 490 & 0.54 & 23,701 & 26.34 & \multirow[t]{3}{*}{89,987} \\
\hline & 1995 & 490 & 0.54 & 23,702 & 26.34 & \\
\hline & 2000 & 490 & 0.54 & 15,296 & 17.00 & \\
\hline \multirow[t]{3}{*}{ V } & 1987 & 1,057 & 2.28 & 9,319 & 20.14 & \multirow[t]{3}{*}{46,275} \\
\hline & 1995 & 1,057 & 2.28 & 9,319 & 20.14 & \\
\hline & 2000 & 1,057 & 2.28 & 4,915 & 10.62 & \\
\hline \multirow[t]{3}{*}{ VI } & 1987 & 964 & 0.81 & 25,232 & 21.08 & \multirow[t]{3}{*}{119,710} \\
\hline & 1995 & 964 & 0.81 & 25,232 & 21.08 & \\
\hline & 2000 & 964 & 0.81 & 23,104 & 19.30 & \\
\hline
\end{tabular}

Forests including high density forests and low density forests; grasslands only including high cover grasslands; total area referring to the whole subregions area 
Table 3 Landuse transfer matrix from 1987 to 1995 (ha)

\begin{tabular}{|c|c|c|c|c|c|c|c|c|c|c|c|c|}
\hline \multirow[t]{2}{*}{1987} & \multicolumn{12}{|l|}{1995} \\
\hline & $\begin{array}{l}\text { High } \\
\text { density } \\
\text { Forests }\end{array}$ & $\begin{array}{l}\text { Low } \\
\text { density } \\
\text { Forests }\end{array}$ & $\begin{array}{l}\text { High } \\
\text { Cover } \\
\text { Grasslands }\end{array}$ & $\begin{array}{l}\text { Manual } \\
\text { Rivers and } \\
\text { Dikes }\end{array}$ & $\begin{array}{l}\text { Reservoirs } \\
\text { and Ponds }\end{array}$ & $\begin{array}{l}\text { Tidal } \\
\text { Flats }\end{array}$ & Bottomlands & $\begin{array}{l}\text { Urban } \\
\text { Building } \\
\text { Lands }\end{array}$ & $\begin{array}{l}\text { Rural } \\
\text { Resident }\end{array}$ & $\begin{array}{l}\text { Other } \\
\text { Building } \\
\text { Lands }\end{array}$ & $\begin{array}{l}\text { Paddy } \\
\text { Field } \\
\text { Lands }\end{array}$ & $\begin{array}{l}\text { Dry } \\
\text { Farming } \\
\text { Lands }\end{array}$ \\
\hline $\begin{array}{l}\text { High density } \\
\text { forests }\end{array}$ & 4,489 & 0 & 0 & 0 & 0 & 0 & 0 & 0 & 0 & 0 & 0 & 0 \\
\hline $\begin{array}{l}\text { Low density } \\
\text { forests }\end{array}$ & 0 & 554 & 0 & 0 & 0 & 0 & 0 & 0 & 0 & 0 & 0 & 0 \\
\hline $\begin{array}{l}\text { High cover } \\
\text { grasslands }\end{array}$ & 0 & 0 & 102,843 & 0 & 0 & 0 & 0 & 0 & 0 & 0 & 0 & 0 \\
\hline $\begin{array}{l}\text { Manual rivers } \\
\text { and dikes }\end{array}$ & 0 & 0 & 0 & 7,410 & 0 & 0 & 0 & 0 & 0 & 0 & 0 & 0 \\
\hline $\begin{array}{l}\text { Reservoirs and } \\
\text { ponds }\end{array}$ & 0 & 0 & 0 & 0 & 9,881 & 0 & 0 & 0 & 6 & 124 & 0 & 311 \\
\hline Tidal flats & 0 & 0 & 0 & 0 & 0 & 64,512 & 0 & 0 & 0 & 0 & 0 & 0 \\
\hline Bottomlands & 0 & 0 & 0 & 0 & 0 & 0 & 270 & 0 & 0 & 0 & 0 & 0 \\
\hline $\begin{array}{l}\text { Urban building } \\
\text { lands }\end{array}$ & 0 & 0 & 0 & 0 & 0 & 0 & 0 & 1,603 & 0 & 0 & 0 & 0 \\
\hline Rural resident & 0 & 0 & 0 & 0 & 0 & 0 & 0 & 0 & 11,693 & 0 & 0 & 1 \\
\hline $\begin{array}{l}\text { Other building } \\
\text { lands }\end{array}$ & 0 & 0 & 0 & 0 & 0 & 0 & 0 & 0 & 0 & 61,955 & 0 & 0 \\
\hline Paddy field lands & 0 & 0 & 0 & 0 & 5 & 0 & 0 & 6 & 0 & 0 & 51,644 & 0 \\
\hline $\begin{array}{l}\text { Dry farming } \\
\text { lands }\end{array}$ & 0 & 0 & 46 & 0 & 128 & 0 & 0 & 24 & 145 & 0 & 0 & 253,823 \\
\hline
\end{tabular}

The left column reflected the out-transferring landcover, and the top row reflected the in-transferring landcover

land, 9,276 ha to dry land. But there were only 143 ha of land transferred in from reservoirs and ponds. All of this caused a substantial decrease of high cover grasslands. In this period, high cover grassland was mainly transferred to human dominated building land, indicating that human disturbance gradually became more and more intensive in these areas in recent years.

\section{Human modified index (HMI)}

We found that the northern part of the Yancheng coastal region was more disturbed by human activities (Fig. 4). It showed that the highest index value was in subregion I and II, where there were larger rural residential areas and other building land area. This indicated a high degree of exploitation and development. From region III to VI, human activities, especially reclamation, were constrained because of the Red-Crowned Crane National Natural Conserve Area located here, so the HMI was relatively lower.
The Dafeng located at the edge between subregion VI and $\mathrm{V}$ (Fig. 2).

\section{$V$ and $R$ value distribution on the whole region}

From 1987, the region with a $V$ value above 0.3 became smaller and smaller. In 1987, the area $V$ value above 0.3 was 87,780 ha; in 1995 , it was 87,860 ha while in 2000 it was 61,220 ha. The index's distribution pattern showed that the southern, seaneighbor coastal region was more appreciate for Milu reintroduction (Fig. 5).

From 1987, the area of the region with a $R$ value above 0.3 increased remarkably. In 1987, the area was 365,730 ha; in 1995 , it was 366,240 ha and in 2000 , it was 381,140 ha (Fig. 6).

In 2000 the area that $V$ value above 0.3 was nearly $600 \mathrm{~km}^{2}$. If we ideally thought that all these regions were suitable for Milu, the maximum Milu population was 10,000 . In other words, the carrying capacity was no more than 10,000 (Fig. 7). 
Table 4 Landuse transfer matrix from 1995 to 2000 (ha)

\begin{tabular}{|c|c|c|c|c|c|c|c|c|c|c|c|c|}
\hline \multirow[t]{2}{*}{1995} & \multicolumn{12}{|l|}{2000} \\
\hline & $\begin{array}{l}\text { High } \\
\text { Density } \\
\text { Forests }\end{array}$ & $\begin{array}{l}\text { Low } \\
\text { Density } \\
\text { Forests }\end{array}$ & $\begin{array}{l}\text { High } \\
\text { Cover } \\
\text { Grasslands }\end{array}$ & $\begin{array}{l}\text { Manual } \\
\text { Rivers and } \\
\text { Dikes }\end{array}$ & $\begin{array}{l}\text { Reservoirs } \\
\text { and Ponds }\end{array}$ & $\begin{array}{l}\text { Tidal } \\
\text { Flats }\end{array}$ & Bottomlands & $\begin{array}{l}\text { Urban } \\
\text { Building } \\
\text { Lands }\end{array}$ & $\begin{array}{l}\text { Rural } \\
\text { Resident }\end{array}$ & $\begin{array}{l}\text { Other } \\
\text { Building } \\
\text { Lands }\end{array}$ & $\begin{array}{l}\text { Paddy } \\
\text { Field } \\
\text { Lands }\end{array}$ & $\begin{array}{l}\text { Dry } \\
\text { Farming } \\
\text { Lands }\end{array}$ \\
\hline $\begin{array}{l}\text { High density } \\
\text { forests }\end{array}$ & 4,489 & 0 & 0 & 0 & 0 & 0 & 0 & 0 & 0 & 0 & 0 & 0 \\
\hline $\begin{array}{l}\text { Low density } \\
\text { forests }\end{array}$ & 0 & 554 & 0 & 0 & 0 & 0 & 0 & 0 & 0 & 0 & 0 & 0 \\
\hline $\begin{array}{l}\text { High cover } \\
\text { grasslands }\end{array}$ & 0 & 0 & 76,576 & 0 & 9,571 & 0 & 0 & 0 & 0 & 7,466 & 0 & 9,276 \\
\hline $\begin{array}{l}\text { Manual rivers } \\
\text { and dikes }\end{array}$ & 0 & 0 & 0 & 7,410 & 0 & 0 & 0 & 0 & 0 & 0 & 0 & 0 \\
\hline $\begin{array}{l}\text { Reservoirs and } \\
\text { ponds }\end{array}$ & 0 & 0 & 143 & 0 & 9,356 & 0 & 0 & 0 & 0 & 14 & 0 & 501 \\
\hline Tidal flats & 0 & 0 & 0 & 0 & 0 & 64,512 & 0 & 0 & 0 & 0 & 0 & 0 \\
\hline Bottomlands & 0 & 0 & 0 & 0 & 0 & 0 & 270 & 0 & 0 & 0 & 0 & 0 \\
\hline $\begin{array}{l}\text { Urban building } \\
\text { lands }\end{array}$ & 0 & 0 & 0 & 0 & 0 & 0 & 0 & 1,633 & 0 & 0 & 0 & 0 \\
\hline Rural resident & 0 & 0 & 0 & 0 & 0 & 0 & 0 & 0 & 11,831 & 0 & 0 & 14 \\
\hline $\begin{array}{l}\text { Other building } \\
\text { lands }\end{array}$ & 0 & 0 & 0 & 0 & 0 & 0 & 0 & 0 & 0 & 62,080 & 0 & 0 \\
\hline $\begin{array}{l}\text { Paddy field } \\
\text { lands }\end{array}$ & 0 & 0 & 0 & 0 & 137 & 0 & 0 & 0 & 2 & 0 & 51,505 & 0 \\
\hline $\begin{array}{l}\text { Dry farming } \\
\text { lands }\end{array}$ & 0 & 0 & 0 & 0 & 1,686 & 0 & 0 & 28 & 19 & 4 & 0 & 252,397 \\
\hline
\end{tabular}

The left column reflected the out-transferring land cover, and the top row reflected the in-transferring land cover

\section{Discussion and conclusion}

From the Milu research reports, we proposed an integrated approach to study the Milu reintroduction strategy. The core part of this analysis was to reflect the Milu favorite habitat choice through the land-cover data. Our analysis may answer the question posed in the introduction: how to assess the Chinese Yancheng

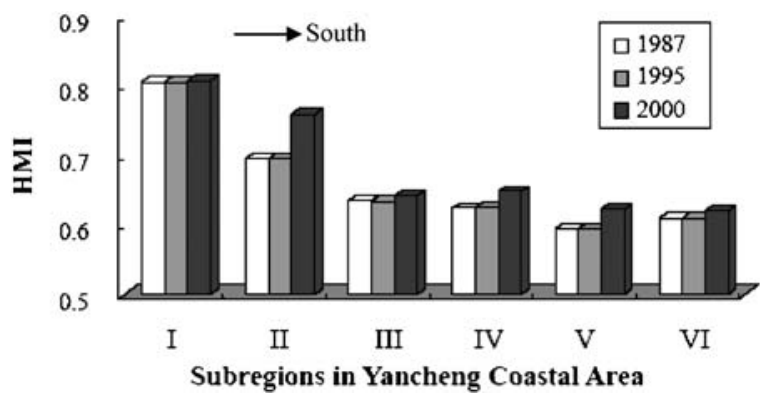

Fig. 4 HMI index value in each subregion. Human modified index (HMI) analysis results showed the HMI heterogeneity pattern between subregions. In the northern Yancheng coastal region, HMI was higher while in the southern part it was lower coastal region, integrating the landscape dynamics and the Milu population research? We think on the landscape scale, only when the landscape metrics are linked with some ecological processes, landscape pattern analysis then can provide some useful information. In this study, we used simple $V$ and $R$ indexes and the specially chosen land-cover type to link the Milu habitat choosing process and the land-use and land-cover change pattern. The results gave us some useful ideas on how to reintroduce Milu on the Yancheng coast.

Then we come to the second question: How to reintroduce Milu in Chinese Yancheng coast according our assessment? Integrating the results, we suggested that the appropriate Milu release pattern was to take the Dafeng as the core, then to establish a diffusing corridor with the coast taken as the key corridor. The key corridor in the coast should extend more to the south. We gave a roughly estimated carrying capacity for reintroducing Milu on Yancheng coast: 10,000 . In fact, for the habitat that has been largely developed in recent years, more habitats have 

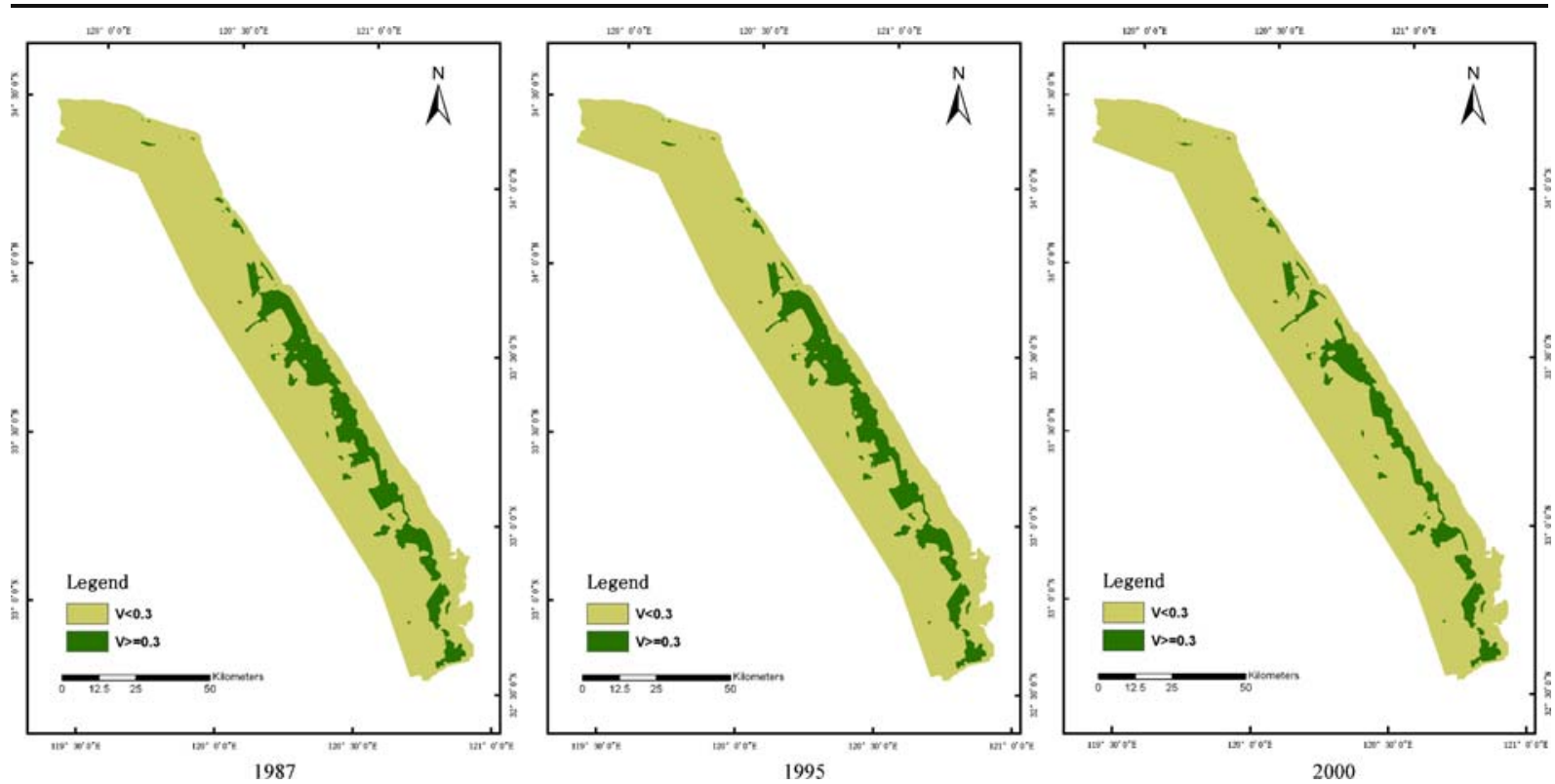

Fig. $5 V$ index spatial analysis on the whole coast of Yancheng. The region suitable for Milu reintroduction decreased faster from 1987. The suitable region, which is mainly located in the southeastern coast, had became more fragmented in recent time

been fragmented. This number of 10,000 is more a methods explanation, but we are sure that this is the maximum size of the future Milu population. Furthermore, our analysis showed that the most urgent issue was to reserve more habitats for biodiversity conservation, and this analysis may provide the policy-makers with some information. In the highly human dominated landscapes in China, there is always a trade-off between development and biodiversity conservation. This analysis might provide the decision-makers with some information about: why to reserve some habitats, where and how. Of course, if we can know the accurate threshold level that makes the habitat unacceptable to the deer, which could be
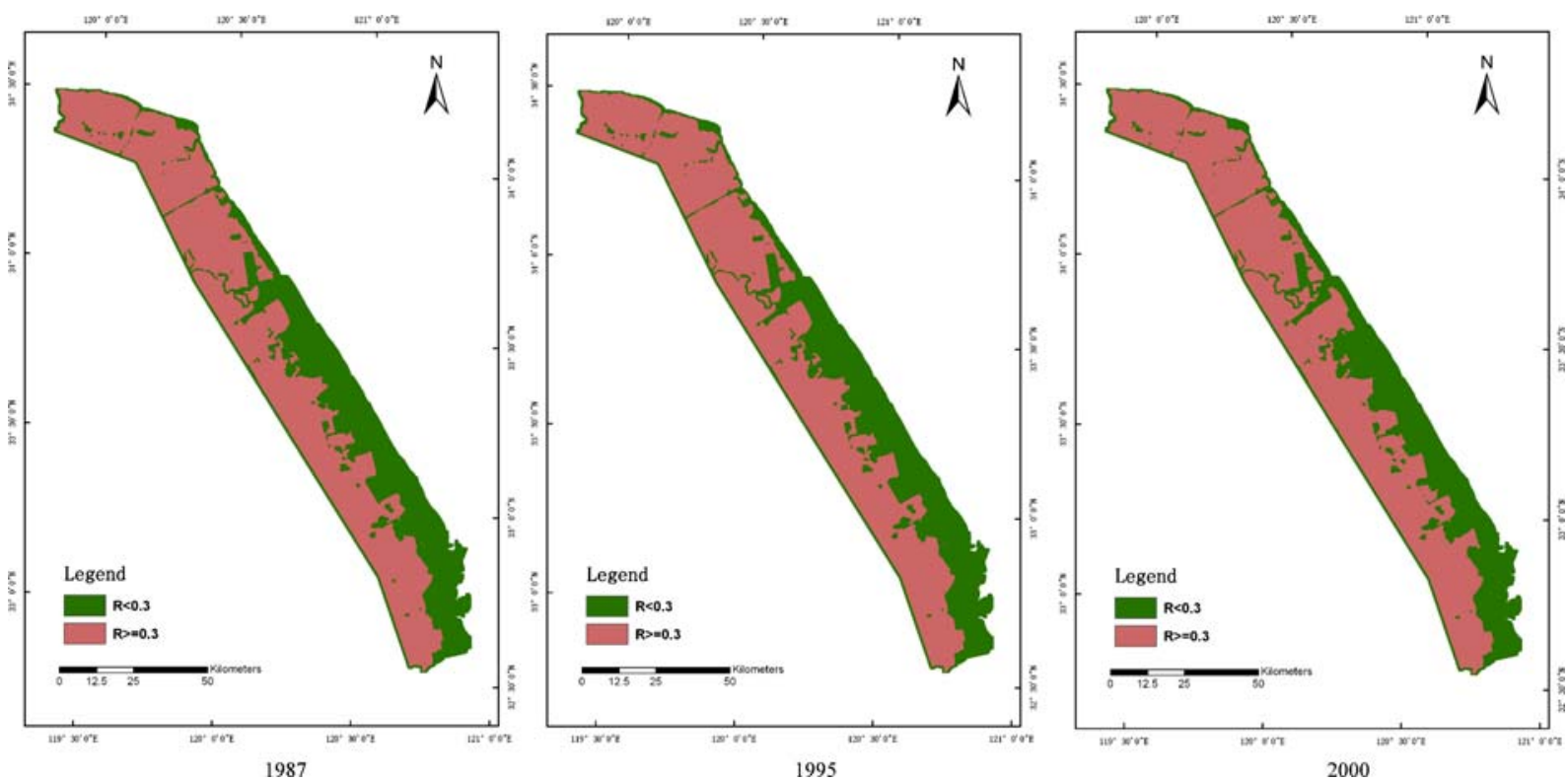

Fig. $6 R$ index spatial analysis on the whole coast of Yancheng. The region with high $R$ value has been enlarged in recent times, and the region has sprawled from the inland to the coast 


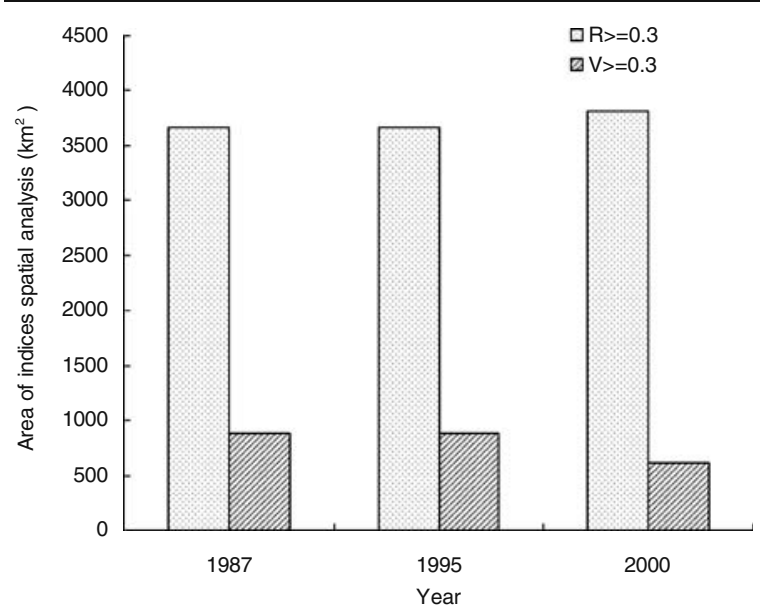

Fig. 7 Area of indices spatial analysis. There was a much larger area with a value of $R$ above 0.3 than that of $V$ above 0.3 , and in recent years this trend has intensified. More suitable potential habitat has been developed and become unsuitable for Milu

measurable by the indices we provide, we could give more accurate and plausible spatial strategy for Milu reintroduction. This should be the work of the future.

Because of the data constraints, we only considered forest and high cover grassland in the suitability assessment index, and agriculture and some building lands in risk assessment index. If there is enough detailed Milu's behavioral research data, theoretically we consider that the $V$ and $R$ indices should be computed as follows:

$V=W_{1} P_{1}+W_{2} P_{2}+W_{3} P_{3}+\ldots W_{n} P_{n}$

$R=W_{1} P_{1}+W_{2} P_{2}+W_{3} P_{3}+\ldots W_{k} P_{k}$

where $W_{i}$ and $P_{i}$ are the $i$ th land-use type's weight and area percentage in the statistical circles, when computing the $V$ and $R$ indices value. This more detailed computing process would be more robust for research on the target species. In this study, we only consider the food and shelter needs for Milu. In fact, Milu need different detailed habitats in their life history (Ding 2005). So if we can know what kinds of vegetation are selected as food at different time of the year, with the detailed land-cover map through the high resolution image interpretation, we can obtain the more accurate and convincingly results. Research on the issue of Milu's habitat choosing process in its life history should continue.
Our ultimate aim is to restore the Milu metapopulation on the Yancheng coast. This work is to highlight the urgency that some priority coastal region should be reserved for Milu reintroduction. The main management issue for Milu reintroduction is the trade-off between development and Milu protection. Scenario analysis, with the involvement of policymakers, native farmers, scientists and investors should be an effective way to resolve this issue (Peterson et al. 2003). This should be done in the near future.

Wikramanayake et al. (2004) provided an ecologybased method for defining priorities for large mammal conservation, taking the tiger as a case study. In the analysis the habitat dynamics through a time series could not be reflected. Furthermore, compared with this analysis, our approach is simpler and more flexible.

Two kinds of methods are adopted in biodiversity conservation: species-based and ecosystem-based (Erwin 1991; Franklin 1993; Poiani et al. 2000; Hoctor et al. 2000). In a species-based approach, conservation areas are selected based on the habitat needs of a species. The ecosystem-based conservation approach tries to maintain the ecological integrity through spatially significant regional conservation. It avoids the basic theory dilemma and understands the ecosystem from the integrated view and not the analytical view (Noss 1987a, b; 1992; Poiani et al. 2000). In the absence of detailed information on the biology and location of an umbrella species, the ecosystem-based approach becomes the alternative approach (Poiani et al. 2000). We think this integrated approach might be an alternative species-based approach for large endangered vertebrates' conservation when there are data constraints (Wikramanayake et al. 1998, 2004). Furthermore, this approach is flexible and the assessment could become more robust with the deeper research continuing. Integrating with the population research information, this approach could link different scale information together. Any factors that affect the vegetation on different scale could also be involved in this analyzing process.

GAP analysis has been taken as an effective approach to identify the gap areas which are potential habitats that should be conserved on large scale (Burley 1988; Jennings 2000). The key step during the analyzing process is to determine the biodiversity description index (A Handbook for Conducting Gap Analysis 2000). GAP analysis considers a lot of detailed information such as vegetation distribution, 
lands authority, species distribution predicting and status quo habitats (Davis 1996; Edwards 1996). But it has been more constrained when used in developing countries like China, for lack of enough detailed information. Furthermore, in fast developing countries like China, because of high human population pressure, almost all lands are developed. The main crisis in these countries is to propose a scientific project to reserve more land for biodiversity conservation before they are over developed.

The main character of this integrated assessment approach used in this article is that it considered all points, lines and area information together. The rapid development of remote sensing technique in recent years has provided technical support to obtain the real time land-use data. Through the areas landscape analysis, we could determine the landscape's changing mode and its corresponding driving mechanism. This integration of both dynamic and static analysis methods may be helpful to realize the scenario modeling that combines the target species requirements and habitat change (Akcakaya et al. 2004; Wintle et al. 2005). But it should be pointed out that this integrating approach can not replace field ground truth survey. We think it is complementary to them when there are time and data constraints, especially in fast developing countries with high human pressures.

Acknowledgements We will give all our sincere thanks to Professor A.P. Cracknell for his valuable suggestions and revisions to the manuscript. This work is partially supported by Natural Scientific Foundation of China (No. 30400054), State Administration of Forestry of China 948 project (No. 2005-4-13), and the Fund for Young Distinguished Professors established by the Chinese Ministry of Education (2002002) for financial aids.

Open Access This article is distributed under the terms of the Creative Commons Attribution Noncommercial License which permits any noncommercial use, distribution, and reproduction in any medium, provided the original author(s) and source are credited.

\section{References}

A Handbook for Conducting Gap Analysis (2000). Retrieved from http://www.gap.unidaho.edu/handbook.

Abbruzzese, B., \& Leibowitz, S. G. (1997). A synoptic approach for assessing cumulative impacts to wetlands. Environmental Management, 21, 457-475.

Akcakaya, H. R., Radeloff, V. C., Mladenoff, D. J., \& He, H. S. (2004). Integrating landscape and metapopulation modeling approaches: viability of the sharp-tailed grouse in a dynamic landscape. Conservation Biology, 18, 526-537.
Beijing Milu Ecological Experimental Center (2005). Collection of theses on Milu research. (in Chinese).

Bhagwat, S. A., Kushalappa, C. G., Williams, P. H., \& Brown, N. D. (2005). A landscape approach to biodiversity conservation of sacred groves in the Western Ghats of India. Conservation Biology, 19, 1853-1862.

Brooks, R. P. (2003). Monitoring and assessment data use and application: establishing common measurement endpoints for ambient assessments, Juiata Case Study. (National Biological Assessment and Criteria Workshop, WET101-11).

Brooks, R. P., Wardrop, D. H., \& Bishop, J. A. (2004). Assessing wetland condition on a watershed basin in the mid-Atlantic region using synoptic land-cover maps. Environmental Monitoring and Assessment, 94, 9-22.

Brown, M. T., \& Vivas, M. B. (2005). A landscape development intensity index. Environmental Monitoring and Assessment, 101, 289-309.

Burel, F., \& Baudry, J. (2005). Habitat quality and connectivity in agricultural landscapes: The role of land use systems at various scales in time. Ecological Indicators, 5, 305-313.

Burley, F. W. (1988). Monitoring biological diversity for setting priorities in conservation. In E. O. Wilson (Ed.), Biodiversity (pp. 227-230). National Academy Press: Washington, DC.

Caicco, S. L., Scott, J. M., Butterfield, B., \& Csuti, B. (1995). A Gap analysis of the management status of the vegetation of Idaho (U.S.A.). Conservation Biology, 9, 498-511.

Center for Statistical Ecology and Environmental Statistics (2006). Retrieved from http://www.stat.psu.edu/ gpp/pdfs/.

Danielson, B. J. (1992). Habitat selection, interspecific interactions and landscape composition. Evolutionary Ecology, 6, 399411.

Davis, F. W. (1996). The nature of gap analysis. Bioscience, 46, 74-75.

Ding, Y. H. (2005). Milu research in China. Changchun, Jilin, China: Jilin Science and Technology Press (in Chinese).

Ding, Y. H., Shen, H., Xu, A. H., \& Xie, S. B. (2006). Milu protection and research (Printed collection of thesis). DaFeng Milu National Natural Conserve, Jiangsu, China (in Chinese).

Edwards, T. C. (1996). Data defensibility and gap analysis. Bioscience, 46, 75-76.

Environmental Systems Research Institute (ESRI) (1993). Digital chart of the world. CD-ROM. Redlands, California.

Erwin, T. L. (1991). An evolutionary basis for conservation strategies. Science, 253, 750-752.

Forman, R. T. T. (1995). Land mosaics: the ecology of landscapes and regions. Cambridge: Cambridge University Press.

Franklin, J. K. (1993). Preserving biodiversity: species, ecosystems, or landscapes? Ecological Applications, 3, 202-205.

Gergel, S. E., Turner, M. G., Miller, J. R., Melack, J. M., \& Stanley, E. H. (2002). Landscape indicators of human impacts to riverine systems. Aquatic Science, 64, 118-128.

Hoctor, T. S., Carr, M. H., \& Zwick, P. D. (2000). Identifying a linked reserve system using a regional landscape approach: The Florida ecological network. Conservation Biology, 14, 984-1000.

Jennings, M. D. (2000). Gap analysis: Concepts, methods and recent results. Landscape Ecology, 15, 5-20.

Jiao, Y. M. (2003). Integrated assessment on the landscape pattern and maturity of manual oases in middle reaches of the Heihe River Basin. Dissertation, Chinese Academy of Science. 
Lausch, A., \& Herzog, F. (2002). Applicability of landscape metrics for the monitoring of landscape change: Issues of scale, resolution and interpretability. Ecological Indicators, 2, 3-15.

Lenz, R., \& Peters, D. (2006). From data to decisions-steps to an application-oriented landscape research. Ecological Indicators, 6, 250-263.

Li, X. Z., Jongman, R. H. G., Hu, Y. M., Bu, R. C., Harms, B., \& Bregt, A. K. (2005). Relationship between landscape structure metrics and wetland nutrient retention function: A case study of Liaohe Delta, China. Ecological Indicators, 5, 339-349.

Li, H., \& Reynolds, J. F. (1994). A simulation experiment to quantify spatial heterogeneity in categorical maps. Ecology, $75,2446-2455$

Li, H., \& Wu, J. (2004). Use and misuse of landscape indices. Landscape Ecology, 19, 389-399.

Liu, J. G., OuYa, Z. Y., Taylor, W. W., Groop, R., Tan, Y., \& Zhang, H. M. (1999). A framework for evaluating the effects of human factors on wildlife habitat: the case of Giant Pandas. Conservation Biology, 13, 1360-1370.

Mander, U., Muller, F., \& Wrbka, T. (2005). Functional and structural landscape indicators: upscaling and downscaling problems. Ecological Indicators, 5, 267-272.

McGarigal, K., \& Marks, B. J. (1995). FRAGSTATS: spatial pattern analysis program for quantifying landscape structure. Portland (OR): US Department of Agriculture, Forest Service, Pacific Northwest Research Station. General Technical Report, PNW-GTR- 351. 120.

Miller, S. J., \& Wardrop, D. H. (2006). Adapting the floristic quality assessment index to indicate anthropogenic disturbance in central Pennsylvania wetlands. Ecological Indicators, 6, 313326.

Mladenoff, D. J., Sickley, T. A., Haight, R. G., \& Wydeven, A. P. (1995). A regional landscape analysis and prediction of favorable gray wolf habitat in the northern Great Lakes region. Conservation Biology, 9, 279-294.

Muller, F. (2005). Indicating ecosystem and landscape organization. Ecological Indicators, 5, 280-294.

Noss, R. F. (1987a). Corridors in real landscape: a reply to Simberloff and Cox. Conservation Biology, 1, 159-164.

Noss, R. F. (1987b). Protecting natural areas in fragmented landscape. Natural Areas Journal, 7, 2-13.

Noss, R. F. (1992). The Wildlands Project: Land conservation strategy. Wild Earth (Special Issue), 10-25.

Oja, T., Alamets, K., \& Parnamets, H. (2005). Modelling bird habitat suitability based on landscape parameters at different scales. Ecological Indicators, 5, 314-321.

Olsen, L. M., Dale, V. H., \& Foster, T. (2007). Landscape patterns as indicators of ecological change at Fort Benning, Georgia, USA. Landscape and Urban Planning, 79, 137-149.

O’Neill, R. V., Hunsaker, C. T., Jones, K. B., Riitters, K. H., Wickham, J. D., Schwartz, P. M., et al. (1997). Monitoring environmental quality at the landscape scale. Bioscience, 47, 513-519.

O’Neill, R. V., Krummel, J. R., Gardner, R. H., Sugihara, G., Jackson, B., DeAngelis, D. L., et al. (1988). Indices of landscape pattern. Landscape Ecology, 1, 153-162.

Patil, G. P., \& Taillie, C. (2001). Use of best linear unbiased prediction for hot spot identification in two-way compositing. Environmental and Ecological Statistics, 8, 163-169.
Peterson, G. D., Cumming, G. S., \& Carpenter, S. R. (2003). Scenario planning: a tool for conservation in an uncertain world. Conservation Biology, 17, 358-366.

Poiani, K. A., Merrill, M. D., \& Chapman, K. A. (2000). Identifying conservation-priority areas in a fragmented Minnesota landscape based on the umbrella species concept and selection of large patches of natural vegetation. Conservation Biology, 15, 513-522.

Riitters, K. H. (2005). Downscaling indicators of forest habitat structure from national assessments. Ecological Indicators, 5, 273-279.

Riitters, K. H., O’Neill, R. V., Hunsaker, C. T., Wichham, J. D., Yankee, D. H., Timmins, K. B. J., \& Jackson, B. L. (1995). A factor analysis of landscape pattern and structure metrics. Landscape Ecology, 10, 23-39.

Schindler, S., Poirazidis, K., \& Wrbka, T. (2008). Towards a core set of landscape metrics for biodiversity assessments: a case study from Dadia National Park, Greece. Ecological Indicators, 8, 502-514.

Scott, J. M., Jennings, M., \& Wright, R. G. (1996). Landscape approaches to mapping biodiversity. BioScience, 46, 77-78.

Sepp, K., \& Bastian, O. (2007). Studying landscape change: indicators, assessment and application. Landscape and Urban Planning, 79, 125-126.

Shugart, H. H. (1998). Terrestrial ecosystems in changing environments. Cambridge: Cambridge University Press.

Turner, M. G., \& Gardner, R. H. (1990). Quantitative methods in landscape ecology: the analysis and interpretation of landscape heterogeneity. New York: Springer.

Turner, M. G., Gardner, R. H., \& O'Neill, R. V. (2001). Landscape ecology in theory and practice, pattern and process. Berlin: Springer.

Uuemaa, E., Roosaare, J., \& Mander, U. (2005). Scale dependence of landscape metrics and their indicatory value for nutrient and organic matter losses. Ecological Indicators, 5, 350-369.

White, D., Minotti, P. G., Barczak, M. J., Sifneos, J. C., Freemark, K. E., \& Santelmanm, M. V. (1997). Assessing risks to biodiversity from future landscape change. Conservation Biology, 11, 349-360.

Wiggering, H., Dalchow, C., Glemnitz, M., Helming, K., Muller, K., \& Schultz, A. (2006). Indicators for multifunctional land use-linking socio-economic requirements with landscape potentials. Ecological Indicators, 6, 238-249.

Wikramanayake, E. D., Dinersty, E., Robinson, J. G., Karanth, U., Rabinowitz, A., \& Olson, D. (1998). An ecology-based method for defining priorities for large mammal conservation: the tiger as case study. Conservation Biology, 12, 865-878.

Wikramanayake, E., McKnight, M., Dinerstein, E., Joshi, A., Gurung, B., \& Smith, D. (2004). Designing a conservation landscape for tigers in human-dominated environments. Conservation Biology, 18, 839-844.

Wintle, B. A., Bekessy, S. A., Venier, L. A., Pearce, J. L., \& Chisholm, R. A. (2005). Utility of dynamic-landscape metapopulation models for sustainable forest management. Conservation Biology, 19, 1930-1943.

Zeng, H., Guo, Q. H., \& Yu, H. (1999). Spatial analysis of artificial landscape transform in FengGang Town, Dongguan City. Acta Ecologica Sinica, 19, 454-457 (in Chinese with English abstract).

Zonneveld, I. S. (1995). Landscape Ecology. Amsterdam: SPB. 